\title{
Effects of climatic changes on olive fly, Bactrocera oleae (Rossi) population dynamic with respect to the efficacy of its larval parasitoid in Egyptian olive trees
}

\author{
Ahmed Mohamed Ezzat Abd El-Salam ${ }^{*}$ (D) Sadek Abdel-Wahed Salem, Ragab Shaker Abdel-Rahman,
} Hoda Hassan El-Behery and Mona Ahmed Magd Elden

\begin{abstract}
Background: The potential effects of two parameters of climatic change conditions (temperature and relative humidity) on the population dynamics of the olive fly across the two ecological areas in Egypt were studied. The olive trees in El-Behera Governorate are more affected by the olive fly compared to the olive trees in the orchard of El-Fayoum Governorate. In this study, the character of climate change in influencing the dynamics of insect population and associated parasites was discussed at the regional level.

Results: The results exhibited that the olive trees in the coast governorate were more susceptible to the olive fly than the inner governorate. The parasitism percentage was recorded 41.7 and $46.4 \%$ at the beginning of the seasons 2016 and 2017, respectively in El-Fayoum Governorate. In El-Behera Governorate, the maximum parasitism percentage was recorded 49.5\% (2016 season), while the 2017 season, the parasitism percentage was recorded $50.4 \%$. The majority of the ordinary parasite was Psyttalia concolor in the two regions.

Conclusion: The study clarifies that there is a positive correlation between B. oleae abundance and the effects of temperature and its parasitoid, Psyttalia concolor. Further, there is no significance found between the olive fly and relative humidity and its parasitoid populations.
\end{abstract}

Keywords: Bactrocera oleae, Ecology, Natural enemies, Psyttalia concolor, Climatic Changes, Coastal and inner regions, olive trees, Egypt

\section{Background}

Olive fruit fly, Bactrocera oleae (Rossi) (Diptera: Tephritidae), is the majority fatal insect pest for the cultivated olive fruits (Olea europaea L.) worldwide. The widespread distribution of this pest is likely due to the geographical spread of olive growing operations (Abd El-Salam et al. 2018). The olive fruit flies caused grave qualitative and quantitative damage to the olive tree cultivation and consequences with economic and monetary losses (Neuenschwander and Michelakis 1979; Economopoulos et al. 1986; Pontikakos et al. 2012; Abd El-Salam et al. 2019). Kapatos and Fletcher (1986) stated that the olive fruit flies survive in more

\footnotetext{
* Correspondence: ahmedezzat59@yahoo.com

Pests and Plant Protection Department, National Research Centre, El-Bohose St., Dokki, Cairo, Egypt
}

humid, cool climates and hot dry regions (Yokoyama et al. 2006; Ordano et al. 2015). The optimum temperature of insect development is between 20.0 and $30.0^{\circ} \mathrm{C}$. Earlier studies had confirmed the attendance of many natural enemies associated with this insect belong to the group of braconids in the subfamilies Opiinae. Among them, Psyttalia concolor (Szépligeti) (Hymenoptera: Braconidae) has been the most studied (Wang et al. 2011; Garantonakis et al. 2017). The climatic factors could have limited the success of the parasitism, e.g., low winter temperatures, which affect parasitoid survival and abundance of a fruit fly at the beginning of the summer (Delrio et al. 2005; Yokoyama et al. 2008; Benelli et al. 2012; Dimetry et al. 2013).

The aim of work is to study the relationship between the population dynamics of the olive fly, 
Bactrocera oleae (Rossi) and efficacy of its parasitoid, Psyttalia concolor under the climatic changes in two different regions.

\section{Methods}

\section{Location of the experiments}

The study was conducted in two different regions: El-Fayoum Governorate is located on $100 \mathrm{~km}$ in the southwest of Cairo (Middle Egypt) and El-Behera Governorate is a coastal governorate, the city is located $160 \mathrm{~km}$ in the northwest of Cairo (Lower Egypt), in the middle of the western Nile Delta. The selected area was about one Feddan $\left(4200 \mathrm{~m}^{2}\right)$ in each farm. Both farms were olive cultivar (Olea europaea L.) planted with Toffahi variety, the age of trees was 5 years and the tree height is about 3-4 $\mathrm{m}$. The distance between every two trees about $5 \mathrm{~m}$. This variety is used as pickled olives (not for oil production; it contains less than $15 \%$ oil, the pulp has large volume and thick). The dense of trees was about 175 trees/Feddan. The yard has suitable climatic conditions for growing olive trees. The chosen area was quite isolated from other orchards and not received any chemical insecticides or pruning processes for 2 years before starting the experiments. The soil of the experimental zone was sandy soil; the dripping irrigation system was applied. The prevailing temperature and the relative humidity \% were provided by Central Laboratory for Agricultural Climate Research (CLACR).

\section{Population dynamic of Bactrocera oleae and its larval parasitoids}

In this study, the selected area in each orchard was divided into five plots (according to the original directions, North, West, East, South, and Middle). Each plot contains 35 trees. Five randomly trees were selected from each plot as replicates (25 trees representing 5 replicates).

Biweekly samples (20 fruit/tree were collected), i.e., 100 fruits/plot, put in paper bags for inspection in the laboratory of Pests and Plant Protection at the National Research Centre. Fruit samples were incubated under controlled conditions $\left(20.0{ }^{\circ} \mathrm{C} \pm 2.0\right.$ and $65.0 \pm 5.0 \mathrm{RH}$ $\%)$ until the emergence of olive fruit fly adults or the internal parasitoid adults. The olive fruit fly adults and the parasitoids were identified by Dr. Hoda El-Behery, the associated professor of biological control in Pests and Plant Protection Department, National Research Centre. Field sampling were continued for two seasons (2016/ 2017), respectively. Also, the parasitism percentage of Psyttalia concolor was calculated according to Dimetry et al. (2013) as follow:
No.P.concolor parasitoid emergence from B.oleae larvae

$$
\% \text { parasitism }=-------------------\times 100
$$

No.B.oleae larvae

\section{Statistics analysis}

The linear regression analysis was applied to explain the relationship between temperature, relative humidity, olive fly, and parasitoids. The statistical analysis carried out using SPSS program version 16.

\section{Results \\ Population of Bactrocera oleae and its larval parasitoid under prevailing climatic changes}

B. oleae was survived in bitter winters as pupae in the soil while adults used the groves in top of olive tree as a shelter. In the harsh winter, the adults were not powerful to continue reproduction before olive fruits have become attractive for oviposition. The infestation occurred at the end of June and the beginning of July. High temperatures were suitable for the olive fly development (egg-laying and larval survival) at the beginning of July.

Results in Table 1 demonstrated that the olive trees in El-Fayoum Governorate were less affected than the second Governorate by the olive fly. In 2016 and 2017, the infestation began on 1 June in the two regions. ElFayoum farm, the population B. oleae larvae was recorded 12.0 larvae/100 fruit at this time the temperature and the relative humidity were $28.0{ }^{\circ} \mathrm{C}$ and $46.5 \%$ R.H. (2016 season). While in 2017 season, the population recorded was 22.0 larvae/100 fruit at $27.0{ }^{\circ} \mathrm{C}$ and $41.5 \%$ R.H. Subsequently, the olive fly larval numbers gradually increased and reached 51.0 and 66.0 larvae/100 fruits on 1 and 15 September 2016 and 2017 season, respectively. In 2016 season, the temperature and relative humidity were recorded $30.0{ }^{\circ} \mathrm{C}$ and $62.5 \%$ R.H. While in 2017 season, it was $29.5{ }^{\circ} \mathrm{C}$ and $54.0 \%$ R.H. (Fig. 1). In this period, the fruit's maturity, temperature, and relative humidity were optimum to insect development. In ElBehera farm, the data shows some changes, for example, the highest number of recorded larvae was 79.0/100 fruit 15 September 2016 season $\left(29.0{ }^{\circ} \mathrm{C}\right.$ and $54.0 \%$ R.H.). In 2017 season, the highest number recorded larvae was 99.0/100 fruit on 15 September $2017\left(27.0{ }^{\circ} \mathrm{C}\right.$ and 53.5\% R.H.) (Fig. 4). Also, the highest numbers of olive fly larvae were concentrated during the months of July, August, and September in this region. The lower temperature and the higher humidity were recorded in El-Behera Governorate.

Temperature and relative humidity \% illustrated in Figs. 1 and 4 for each region. In El-Behera farm, the recorded parasitoids are Cyrtoptyx latipes Rondani, Eurytoma martellii Domenichini, Pnigalio mediterraneus Ferriere, and Psyttalia concolor Szepligeti. Psyttalia 
Table 1 Numbers of the olive fly, Bactrocera oleae and P. concolor parasitoid that recording in the two regions during 2016/2017 seasons

\begin{tabular}{|c|c|c|c|c|c|c|}
\hline \multirow[t]{2}{*}{ Date of inspection } & \multicolumn{2}{|l|}{$\begin{array}{l}\text { Kom Oshem } \\
\text { El-Fayoum }\end{array}$} & \multirow[t]{2}{*}{$\begin{array}{l}\% \\
\text { Parasitism }\end{array}$} & \multicolumn{2}{|l|}{$\begin{array}{l}\text { Wadi El-Natrun } \\
\text { El-Behera } \\
\end{array}$} & \multirow[t]{2}{*}{$\begin{array}{l}\% \\
\text { Parasitism }\end{array}$} \\
\hline & $\begin{array}{l}\text { Avg. no. B. oleae larvae/ } \\
100 \text { fruit } \pm \text { SE }\end{array}$ & Avg. no. P. concolor & & $\begin{array}{l}\text { Avg. no. B. oleae larvae/ } \\
100 \text { fruit } \pm \text { SE }\end{array}$ & Avg. no. P. concolor & \\
\hline \multicolumn{7}{|l|}{ First season } \\
\hline 1 June 2016 & $12.0 \pm 1.14$ & 2.0 & 16.7 & $42.0 \pm 2.07$ & 3.0 & 7.1 \\
\hline 15 June 2016 & $15.0 \pm 2.07$ & 3.0 & 20.0 & $54.0 \pm 6.3$ & 5.0 & 9.3 \\
\hline 1 July 2016 & $19.0 \pm 2.75$ & 2.0 & 10.5 & $58.0 \pm 3.19$ & 6.0 & 10.3 \\
\hline 15 July 2016 & $31.0 \pm 2.50$ & 3.0 & 9.6 & $61.0 \pm 5.18$ & 4.0 & 6.6 \\
\hline 1 August 2016 & $45.0 \pm 4.9$ & 4.0 & 8.9 & $62.0 \pm 6.63$ & 5.0 & 8.1 \\
\hline 15 August 2016 & $48.0 \pm 3.61$ & 4.0 & 8.3 & $74.0 \pm 3.78$ & 4.0 & 5.4 \\
\hline 1 September 2016 & $51.0 \pm 2.04$ & 3.0 & 5.9 & $76.0 \pm 3.67$ & 2.0 & 2.6 \\
\hline 15 September 2016 & $32.0 \pm 3.14$ & 4.0 & 12.5 & $79.0 \pm 7.95$ & 20.0 & 2.5 \\
\hline 1 October 2016 & $24.0 \pm 2.51$ & 5.0 & 20.8 & $68.0 \pm 7.66$ & 20.0 & 29.4 \\
\hline 15 October 2016 & $22.0 \pm 1.04$ & 3.0 & 13.6 & $40.0 \pm 5.0$ & 15.0 & 37.5 \\
\hline 1 November 2016 & $13.0 \pm 1.41$ & 1.0 & 7.7 & $25.0 \pm 1.87$ & 6.0 & 24.0 \\
\hline 15 November 2016 & $1.0 \pm 0.0$ & 0.0 & 0.0 & $20.0 \pm 1.41$ & 2.0 & 10.0 \\
\hline 1 December 2016 & $0.0 \pm 0.0$ & 0.0 & 0.0 & $0.0 \pm 0.0$ & 0.0 & 0.0 \\
\hline 15 December 2016 & $0.0 \pm 0.0$ & 0.0 & 0.0 & $0.0 \pm 0.0$ & 0.0 & 0.0 \\
\hline \multicolumn{7}{|l|}{ Second season } \\
\hline 1 June 2017 & $22.0 \pm 2.02$ & 3.0 & 13.6 & $38.0 \pm 2.21$ & 6.0 & 15.8 \\
\hline 15 June 2017 & $24.0 \pm 3.19$ & 3.0 & 12.5 & $42.0 \pm 1.51$ & 9.0 & 21.4 \\
\hline 1 July 2017 & $25.0 \pm 3.4$ & 2.0 & 8.0 & $70.0 \pm 6.78$ & 15.0 & 21.4 \\
\hline 15 July 2017 & $26.0 \pm 1.7$ & 2.0 & 7.7 & $73.0 \pm 5.54$ & 20.0 & 27.4 \\
\hline 1 August 2017 & $45.0 \pm 2.36$ & 4.0 & 8.9 & $95.0 \pm 2.98$ & 25.0 & 26.3 \\
\hline 15 August 2017 & $52.0 \pm 6.1$ & 4.0 & 7.7 & $99.0 \pm 4.08$ & 30.0 & 30.3 \\
\hline 1 September 2017 & $57.0 \pm 6.4$ & 5.0 & 8.8 & $97.0 \pm 1.04$ & 33.0 & 34.0 \\
\hline 15 September 2017 & $66.0 \pm 5.4$ & 8.0 & 12.1 & $99.0 \pm 4.08$ & 35.0 & 35.3 \\
\hline 1 October 2017 & $28.0 \pm 3.04$ & 7.0 & 25.0 & $71.0 \pm 3.2$ & 28.0 & 39.4 \\
\hline 15 October 2017 & $23.0 \pm 3.05$ & 4.0 & 17.4 & $39.0 \pm 7.11$ & 8.0 & 20.5 \\
\hline 1 November 2017 & $11.0 \pm 1.48$ & 2.0 & 18.2 & $33.0 \pm 2.12$ & 7.0 & 21.2 \\
\hline 15 November 2017 & $7.0 \pm 1.76$ & 1.0 & 14.3 & $19.0 \pm 2.07$ & 2.0 & 10.5 \\
\hline 1 December 2017 & $1.0 \pm 0.0$ & 0.0 & 0.0 & $8.0 \pm 1.14$ & 1.0 & 12.5 \\
\hline 15 December 2017 & $0.0 \pm 0.0$ & 0.0 & 0.0 & $0.0 \pm 0.0$ & 0.0 & 0.0 \\
\hline
\end{tabular}

concolor was the highest number on $B$. oleae larvae in the region.

The results in Table 1 indicated that the Psyttalia concolor parasitoid population fluctuated between 5.9 and $20.8 \%$ and $7.7-25.0 \%$ during 2016 and 2017 seasons, respectively (Figs. 2 and 3 ).

The previous list of the parasitoids restricted in Table 1 and collection from larval and pupal stages of the olive fly. The results show that the olive trees in El-Behera (humid or coastal zone) farm are more susceptible to olive fly than in El-Fayoum farm (dry or inner zone). This restriction confirmed that, with no use of chemical control, it will return the natural balance that has been lost with the current environmental pollution.

The importance of parasites in reducing the spread and damage of olive flies in El-Fayoum and El-Behera Governorate can be arranged in ascending order according to their spread and importance in the olive farms as follows: Psyttalia concolor; Pnigalio mediterraneus; Eurytoma martellii and Cyrtoptyx latipes and Psyttalia concolor; Cyrtoptyx latipes; Eurytoma martellii and Pnigalio mediterraneus, respectively. Exchange with data illustrated in Fig. 5 and 6 indicated that P. concolor was the highly efficient parasitoid and performance in the Wadi 


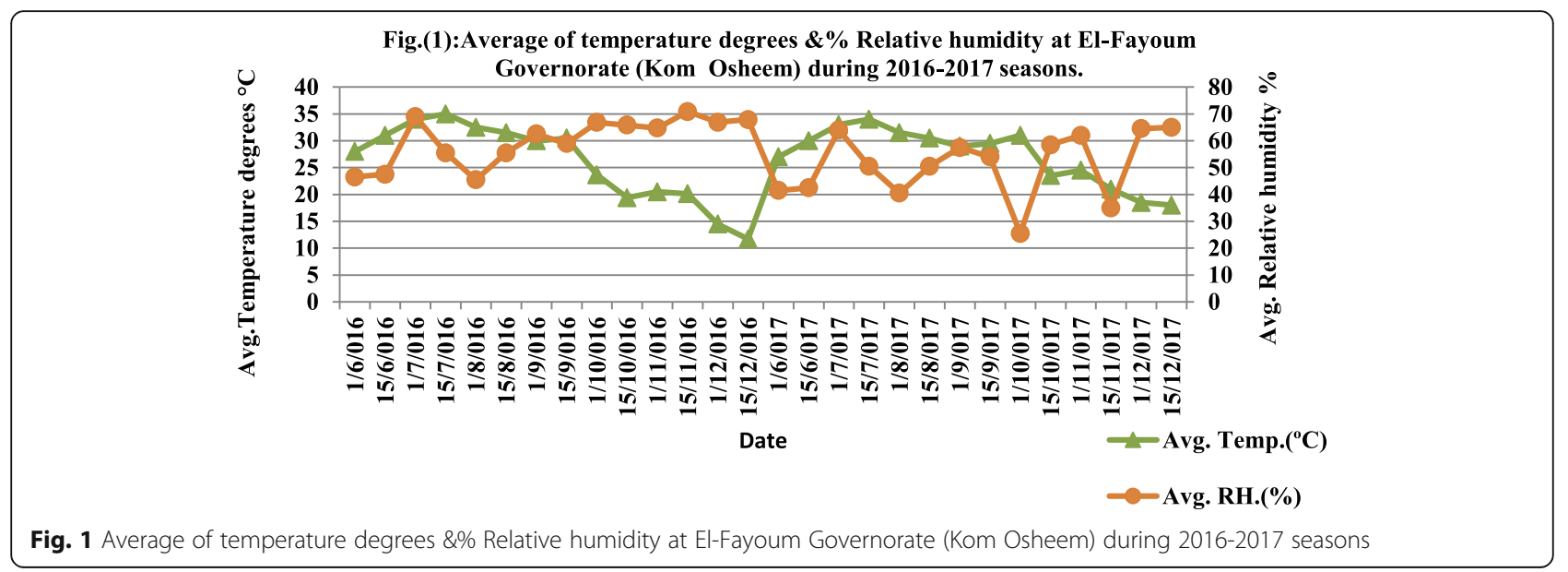

El-Natrun field during two successive years. The results presented that the percentage of the parasitism ranged between $2.5-37.5$ and $10.5-39.4 \%\left(19.9{ }^{\circ} \mathrm{C}\right.$ and $78.5 \%$ R.H. and $28.0{ }^{\circ} \mathrm{C}$ and $54.0 \%$ R.H., respectively) during 2016 and 2017 seasons.

In El-Fayoum farm, Psyttalia concolor exhibited high percentage of parasitism 20.8 and $25.0 \%$ on 10 October 2016 and $2017\left(23.7{ }^{\circ} \mathrm{C}\right.$ and $66.8 \%$ R.H. and $31.0{ }^{\circ} \mathrm{C}$ and $25.5 \%$ R.H., respectively) during the successive seasons (Figs. 2 and 3). Table 2 showed that the different significant were found between $B$. oleae and $P$. concolor populations in each region.

\section{Effect of the climatic changes on $B$. oleae larval infestation by Psyttalia concolor parasitoid}

The data illustrated in Figs. 1, 2, and 3 indicated that in El-Fayoum region, the average temperature and the relative humidity during the 2016 season was $25.9{ }^{\circ} \mathrm{C}$ and $60.3 \% \mathrm{RH}$. While in the 2017 season, the average temperature was increased to record $27.2{ }^{\circ} \mathrm{C}$ and the relative humidity was decreased to record $50.8 \% \mathrm{RH}$.
As for El-Behera region, the average temperature and the relative humidity during 2016 season was $23.9{ }^{\circ} \mathrm{C}$ and $60.6 \% \mathrm{RH}$. In the 2017 season, the average temperature was increased to record $25.5{ }^{\circ} \mathrm{C}$ while the relative humidity was decreased to record 56.8\% $\mathrm{RH}$ (Figs.4, 5, and 6). Both two regions have a climatic change to cause an increase in temperature $\left(+1.3\right.$ and $\left.+1.6{ }^{\circ} \mathrm{C}\right)$ and decrease in the relative humidity low ( -9.5 and $-3.8 \%$ R.H.).

In El-Fayoum Governorate, the data analysis in Table 2 showed that there was significant found between the temperature and $B$. oleae populations $\left(r^{2}=0.492\right)$ during 2016 and 2017 seasons $\left(r^{2}=0.457\right)$. The relative humidity did not have a significant effect during the two seasons. Also, in El-Behera Governorate, the temperature was significant with $B$. oleae populations and the relative humidity was also not significant (Table 3).

The results in Table 2 showed that the linear regression for temperature and relative humidity $\%$ and

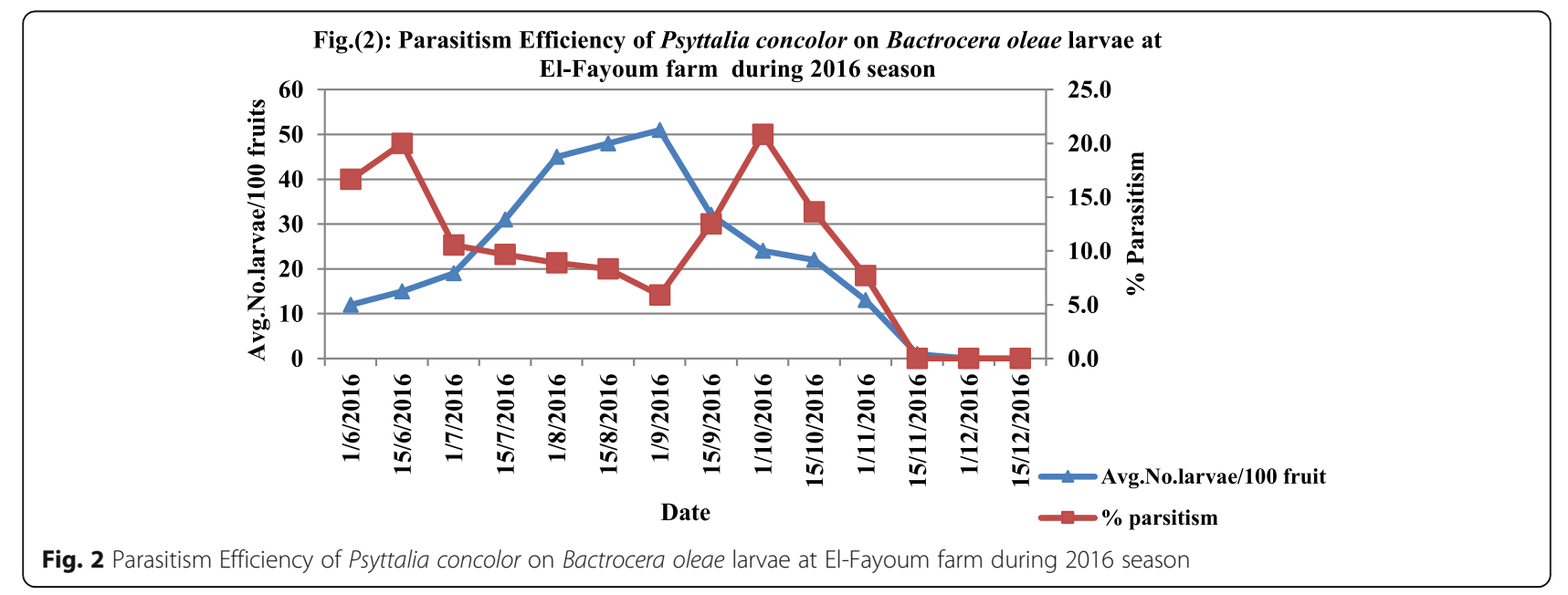


Fig.(3): Parasitism Efficiency of Psyttalia concolor on Bactrocera oleae larvae at El-Fayoum farm during 2017 season

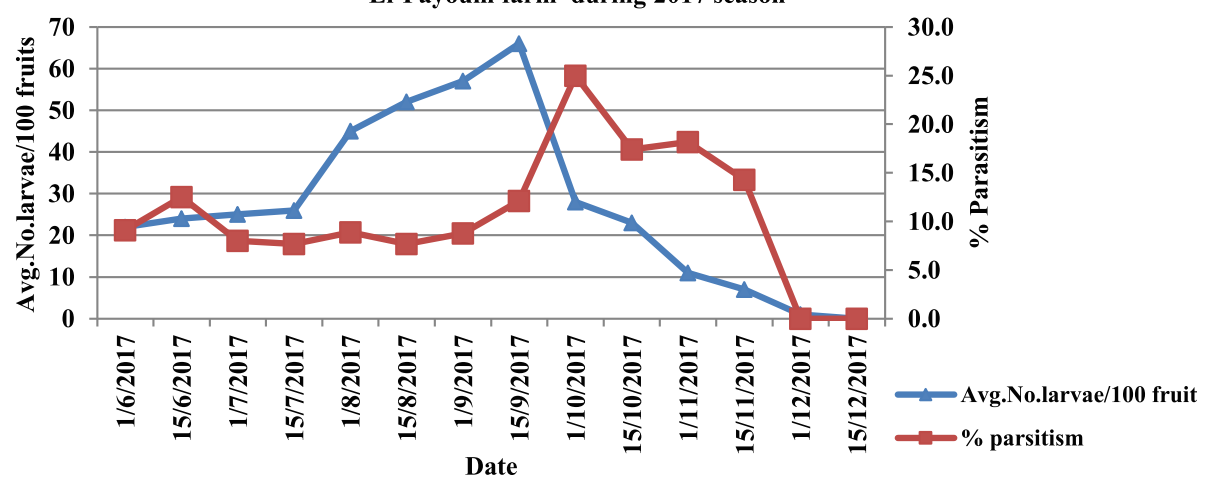

Fig. 3 Parasitism Efficiency of Psyttalia concolor on Bactrocera oleae larvae at El-Fayoum farm during 2017 season

$P$. concolor parasitoid with $B$. oleae numbers in each region during each season.

For example, in El-Fayoum farm during 2016 season, $t$ test indicated that the temperature effect was significant with $B$. oleae fly numbers while the relative humidity $\%$ was not significant. Also, there was significant with temperature and relative humidity \% against $P$. concolor. In 2017 season, the significant effect for temperature and the relative humidity \% were found with $B$. oleae fly and $P$. concolor parasitoid numbers. In El-Behera farm, during the two season, the results showed that the temperature effect was significant with $B$. oleae fly numbers while the relative humidity $\%$ was not significant with olive fly numbers. The temperature and the relative humidity $\%$ were significant against $P$. concolor parasitoid numbers (the noticed that El-Behera Governorat, the relative humidity \% was highly than El-Fayoum Governorate, and this factor may be attributed to the idea that the olive fly was highly active in El-Behera Governorate). The results confirmed that the relative humidity \% in the two regions during the two seasons have no significant effect on $B$. oleae fly numbers.

Table 2 The analytical data concerned with the B. oleae abundance and effects of temperature, relative humidity, and parasitoid during 2016 and 2017 seasons at El-Fayoum Governorate

\begin{tabular}{|c|c|c|c|c|}
\hline Climatic factors & $F$ value & $b$ & Partial regression $\left(r^{2}\right)$ & $t$ value \\
\hline \multicolumn{5}{|c|}{ First season (2016) } \\
\hline Temperature & & 1.186 & 0.492 & $4.532^{*}$ \\
\hline $\mathrm{RH}$ & $29.626^{*}$ & 0.074 & 0.036 & $0.358 \mathrm{NS}$ \\
\hline P. concolor & & 3.359 & 0.403 & $3.320^{*}$ \\
\hline \multicolumn{5}{|c|}{ Second season (2017) } \\
\hline Temperature & & 1.857 & 0.457 & $5.608^{*}$ \\
\hline $\mathrm{RH}$ & $43.536^{*}$ & 0.327 & 0.188 & $2.434 \mathrm{NS}$ \\
\hline P. concolor & & 3.999 & 0.564 & $6.962^{*}$ \\
\hline
\end{tabular}

The results showed that more studies should take care of climate change and its relationship with the growth of insect pests and their natural enemies.

\section{Discussion}

The seasonal effects of weather and ongoing changes in climatic conditions would be a straight guide to modifications in dispersal and growth of insect species. The change of the environment affects the pest population fluctuation either directly or indirectly by the host physiology. Perović and Hrnčić (2013) stated that the activity of the fly was dependent on environmental conditions.

Host availability and the chance of pest outbreaks are further determined by the incidence and quality of abiotic conflict. Also indirectly, the developmental success of insect herbivores was dependent on climate and environmental parameters influence on plant physiology. Insects and plants were exposed to complex interactions among changes in temperature and enlarged levels of $\mathrm{CO}_{2}$ (Karuppaiah and Sujayanad 2012).

Degrees of temperature was one of the abiotic factors that regulate olive fly abundance. High temperatures affect younger developmental stages. Mean daily temperatures above $30.0{ }^{\circ} \mathrm{C}$ can destroy up to $80 \%$ of eggs and larvae. The optimal temperature for pupal development ranged from 22.0 to $25.0{ }^{\circ} \mathrm{C}$. Air humidity is also important for the developmental stages of the fly, particularly, when it is combined with high temperatures over long periods. Olive fruits then lose their moisture, which makes the survival of the immature stages. Temperatures ranging from 20.0 to $26.0^{\circ} \mathrm{C}$ and monthly precipitation of $100 \mathrm{~mm}$ in July, August, and September were favorable for the progress of all stages of the olive fruit fly, while high summer temperatures cause to decrease in the population of B. oleae (Ricci and Ballatori 1982; Lopez-Villalta 1999). Our results clearly showed that the adverse changes of the temperature and humidity led to disturbance of the equilibrium in the relationship 


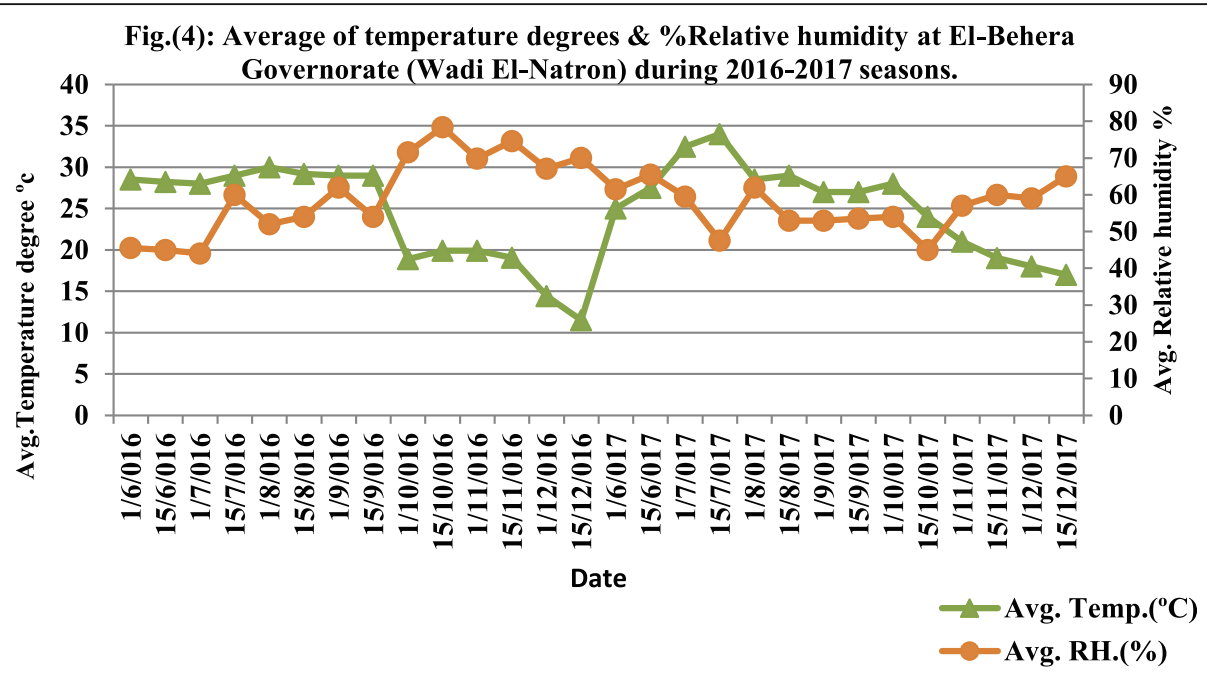

Fig. 4 Average of temperature degrees \& \%Relative humidity at El-Behera Governorate (Wadi El-Natron) during 2016-2017 seasons

between larval olive fly and its larval parasitoid Psyttalia concolor in both regions.

Yokoyama et al. (2006) use the larval parasitoid, Psyttalia concolor, in controlling of olive fruit fly, B. oleae, in olives, Olea europaea. The relative humidity during the releases was significantly higher at the seaboard location. Mean percentage parasitism varies from 0.5 to 4.0 and 1.5 to 30.0 at the seaboard and internal valley locations, respectively. Varikou et al. (2014) stated that $P$. concolor is larval-pupal endoparasitoid able to assail as a minimum fourteen Tephritidae species at dissimilar wild and or cultivated plants, including pests of great economic importance such as Ceratitis capitata and $B$. oleae (Benelli et al. 2012). El-Heneidy et al. (2001) stated that eight parasitoid species were found on the immature stages of the fly (larvae and pupae). All belong to order Hymenoptera: Cyrtoptyx latipes R., Cyrtoptyx sp., Eupelmus sp., Eurytoma sp., Eurytoma martellii M., Macroneura sp., Pnigalio agraules W., and Opius concolor in Egypt. All species were surveyed during July to November. The percentage of the parasitism reached 38.9 and $10.8 \%$ by Opius concolor and Pnigalio agraules, respectively. Olive fruit fly larvae are typically unavailable for parasitism when female $P$. concolor emerge in the spring. Garantonakis et al. (2017) stated that the parasitism percentage was significantly higher $(>30 \%)$ in medium fruit weight than light-weight varieties. The most favorable host fruit for $P$. concolor growth was Mastoidis variety.

A key factor regulating the life history pattern of insect pests is temperature. Because of the insects are poikilothermic (cold-blooded) organisms. Therefore, the developmental rates of their life stages were powerfully needy temperature (Cammell and Knight 1991; Fleming and Volney 1995). Every degree rise in global temperature, the life cycle of insect would be shortened and quickened. The pests population would be high (Harrington et al. 2001; Bale et al. 2002; Samways 2005). Our results

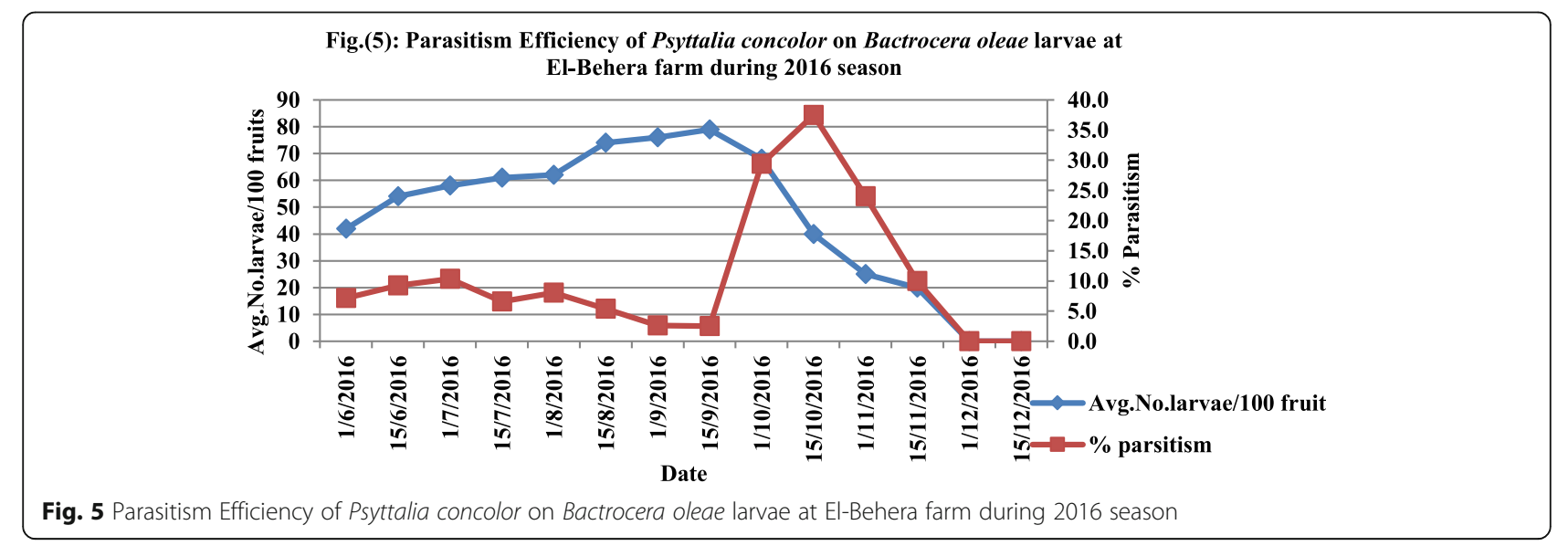


Fig.(6): Parasitism Efficiency of Psyttalia concolor on Bactrocera oleae larvae at El-Behera farm during 2017 season

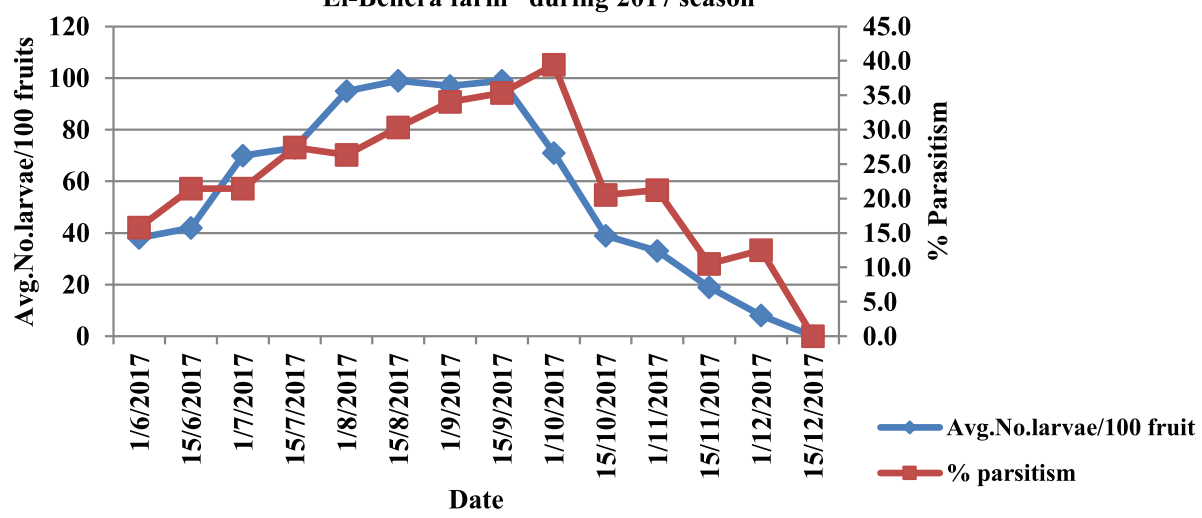

Fig. 6 Parasitism Efficiency of Psyttalia concolor on Bactrocera oleae larvae at El-Behera farm during 2017 season

showed that the positive correlation was found between B. oleae abundance and the temperature degrees and its larval parasitoid. Significant differences were not achieved between B. oleae abundance and the relative humidity and its larval parasitoid in both regions.

Climatic changes lead to that the temperature increases had caused modifies in the species dissimilarity and apportion. It will exchange for the distribution of many insect species in different grades (Hickling et al. 2005). It had been realized that global warming affects the single species and communities in the form of range shifts and extinctions (Walther et al. 2002; Root et al. 2003; Battisti 2004). Effect of temperature on physiology and development insects can be directly or indirectly through the physiology or life of hosts. Some insects can be several years to full one life cycle. These insects (arctic moths) will be inclined to temperate temperature variability over the route of their life history. Crop insect pests numbers are "stop and go" developers in relative to temperature, so they develop extra quickly during periods with appropriate temperatures. It has been

Table 3 The analytical data concerned with the B. oleae abundance and effects of temperature, relative humidity, and parasitoid during 2016 and 2017 seasons at El-Behera Governorate

\begin{tabular}{|c|c|c|c|c|}
\hline Climatic factors & $F$ value & $b$ & Partial regression $\left(r^{2}\right)$ & $t$ value \\
\hline \multicolumn{5}{|c|}{ First season (2016) } \\
\hline Temperature & & 4.258 & 0.924 & $8.979^{*}$ \\
\hline $\mathrm{RH}$ & $56.307^{*}$ & 0.489 & 0.194 & $1.825 \mathrm{NS}$ \\
\hline P. concolor & & 1.703 & 0.332 & $4.782^{*}$ \\
\hline \multicolumn{5}{|c|}{ Second season (2017) } \\
\hline Temperature & & 2.130 & 0.317 & $6.348^{*}$ \\
\hline $\mathrm{RH}$ & $214.747^{*}$ & 0.006 & 0.001 & $0.026 \mathrm{NS}$ \\
\hline P. concolor & & 1.946 & 0.715 & $14.008^{*}$ \\
\hline
\end{tabular}

assessed that with a $2.0{ }^{\circ} \mathrm{C}$ temperature increase, insects might increase from one to five additional life cycles for each season (Yamamura and Kiritani 1998). In a recent study, Abd El-Salam et al. (2019) found that in the moist region, El-Behera (2017 season), positive correlation and significant were found between the temperature and the numbers of olive fly. While the negative correlation was found between relative humidity $\%$ and the numbers of olive fly with traps. This result gives an indication that there is a climate change that occurred from 2016 to 2017. Warming weather could decrease the occurrence of severe cold events which could enlarge the overwintering locale for insect pests (Patterson et al. 1999). The effects of warming could be increased levels of feeding and growth, including the possibility of additional generations in a given year (Cannon 1998). Migratory insects might arrive earlier to the area which they were able to bitter winter till be expanded. Natural enemies and host insect populations might be responding differently to changes in temperature. Parasitism could be reduced if host populations emerge and pass through vulnerable life stages before parasitoids emerge. Hosts might be passing through vulnerable life stages more quickly at higher temperatures, reducing the window of opportunity for parasitism. The temperature might change sex ratios of some pest species such as thrips (Lewis 1997) potentially affecting reproduction rates. However, insects that spend important parts of their life history in the soil might be extra slowly affected by temperature changes than above ground. This was because soil provides an insulating intermediate that will be likely to bumper temperature changes more than the air (Bale et al. 2002). In lower winter, the mortality of insects could be important in increasing insect populations (Harrington et al. 2001). There was also the prospect of new pests which might be become much more important as a result of increased temperature due to global warming. 
Climate change is likely to involve a higher frequency of abiotic disturbance. Depending on the dimension of the disturbance, local to regional dynamics of insect populations and species composition will be strongly affected insects find optimum conditions for development within a certain range of temperature limited by speciesspecific lower and upper developmental thresholds. These alterations and gradual changes might be affected by the population dynamic parameters like development and reproduction, diapauses and winter mortality, and flight and dispersal (Bale et al. 2002). There were few scientific evidence on the effect of precipitation on insect pest population and their growth. Some insects were sensitive to precipitation and are killed or removed from crops by heavy rains. In some northeastern US states, this consideration is important when choosing management options for onion thrips. However, some insects that bitter winter in the soil, such as cranberry fruit worm and other cranberry insect pests, flooding the soil had been used as a control measure (Vincent et al. 2003). It is predicted that more common and strong precipitation actions predicated throughout climate might change have negative impacts on these insect pest populations. Temperature and precipitation changes could impact insect pest predators, parasites, and diseases resulting in a composite dynamic mode. Fungal pathogens of insects were favored by high humidity, and their incidence would increase by climate changes that grow longer periods of high humidity and reduced by those that result in drier conditions.

\section{Conclusion}

Climate change had become a key worry in this era, especially in agriculture. The increase in temperature and consequentiality is affected by the relative humidity, whether high or low, resulting in the effect on the natural plant growth from early or delayed growth. Also, the organisms, the insect pests, and the associated biological enemies were changed from its development. However, there is excessive insects or disappearance of these types of insects. In this study, the two consecutive years showed positive and negative relations between the survey of the olive fly and parasites associated with it. The results revealed that the linear regression for the temperature and $P$. concolor parasitoid with $B$. oleae numbers were significant. While the relative humidity $\%$ was no significant effect for during the two seasons.

The results showed that the role of temperature would be more effective than relative humidity $\%$ on $B$. oleae fly and its larval parasitoid.

The results indicated that the numbers of the parasitoids were increased from the first season to the second season. We noticed that the parasitoids percentage was increased during the two seasons. We expect that the average annual temperature rise over the next 10 years will lead to a decrease in the population of the olive fly due to the non-adaptation of heat to its various stages and the death of large numbers of them. Of course, the parasite population will decrease as a result of the lack of a host preferred.

On the other hand, the insect may become more virulent and adapts to constant thermal changes.

Further, more studies should be carried out on climatic changes and their relationship with the development of insect pests and their natural enemies.

\section{Acknowledgements \\ Thanks to the National Research Centre for the support and facilities which are supplemental in publication of this manuscript through the project entitled "Management strategy of climate change effects on pest control and yield of olive trees." (code no. 11080309). The authors also thank Dr. Wael Mahmoud Marzouk of the Agricultural Research Center for conducting the statistical analysis of the results of the manuscript.}

\section{Authors' contributions}

AME designed the experiments, wrote the manuscript, analyzed the data, and published it. SA designed, performed the experiments, and reviewed the manuscript. RS designed, performed the experiments, and collected data. $\mathrm{HH}$ identified the parasites and collected the samples. MMED reviewed and contributed to the collection of the results. All authors read and approved the final version of the manuscript.

\section{Funding}

National Research Centre (project: management strategy of climate change effects on pest control and yield of olive trees (code no. 11080309).

Availability of data and materials

Not applicable

Ethics approval and consent to participate

Not applicable

Consent for publication

Not applicable

\section{Competing interests}

The authors declare that they have no competing interests.

Received: 26 November 2018 Accepted: 23 October 2019

Published online: 05 December 2019

\section{References}

Abd El-Salam AME, Salem SA, El-Kholy MY, Abdel-Rahman RS (2018) The repellent and toxic effects of some eco-friendly formulations against the important olive tree insects in Egypt. Biosci Res 15(4):3914-3925

Abd El-Salam AME, Salem SA, El-Kholy MY, Abdel-Rahman RS, Abdel-Raheem MA (2019) Role of the olive fly, Bactrocera oleae (Rossi) traps in integrated pest management on olive trees under climatic change conditions in Egypt. Plant Archives, 19, Supplement 2, 457-461

Bale J, Masters G, Hodkinson I, Awmack C, Jnbezemer TM, Brown VK, Butterfield J, Buse A, Coulson JC, Farrar J, Good JG, Harrington R, Hartley S, Jones TH, Lindroth L, Press M, Mrnioudis I, Watt A, Whittaker A (2002) Herbivory in global climate change research: direct effects of rising temperature on insect herbivores. J Global Change Biol 8:1-16

Battisti A (2004) Forests and climate change - lessons from insects. Forest. 1:17-24

Benelli G, Revadi S, Carpita A, Giunti G, Raspi A, Anfora G, Canale A (2012) Behavioral and electrophysiological responses of the parasitic wasp Psyttalia concolor (Szépligeti) (Hymenoptera: Braconidae) to Ceratitis capitates induced fruit volatiles. Biol Control 64:116-124

Cammell ME, Knight JD (1991) Effects of climate change on the population dynamics of Crop pests. Adv Ecol Res 22:117-162 
Cannon RJC (1998) The implications of predicted climate change for insect pests in the UK, with emphasis on non-indigenous species. Glob Chang Biol 4:785-796

Delrio G, Lentini A, Satta A (2005) Biological control of olive fruit fly through inoculative releases of Opius concolor Szépl. Integrated Protection of Olive Crops. IOBC/WPRS Bull 28(9):53-58

Dimetry NZ, El-laithy A, Abd El-Salam AME, El-Saiedy AE (2013) Management of the major piercing sucking pests infesting cucumber under plastic house conditions. Arch Phytopathol Plant Protect 46(2):158-171

Economopoulos AP, Raptis A, Stavropoulou-Delivoria A, Papadopoulos A (1986) Control of Dacus oleae by yellow sticky traps combined with ammonium acetate slow-release dispensers. Entomologia Experimentalis et Applicata 41:11-16

El-Heneidy AH ,Omer AH, El-Sherif H, Khawas MA (2001) Survey and seasonal abundance of parasitoids of the olive fruit fly, Bacterocera (Dacus) oleae Gmel. (Diptera : Trypetidae ) in Egypt. Arab J.PI.Prot., 19:80-85.

Fleming RA, Volney WJ (1995) Effects of climate change on insect defoliator population processes in Canada's boreal forests: some plausible scenarios. Water Air Soil Pollut 82:445-454

Garantonakis N, Varikou K, Birouraki A (2017) Parasitism of Psyttalia concolor (Hymenoptera: Braconidae) on Bactrocera oleae (Diptera: Tephritidae) infesting different olive varieties. Phytoparasitica 45:461-469

Harrington R, Fleming R, Woiwod I (2001) Climate change impacts on insect management and conservation in temperate regions: can they be predicted? Agric For Entomol 3:233-240

Hickling R, Roy DB, Hill JK, Thomas CD (2005) A northward shift of range margins in British Odonata. Glob Chang Biol 11:502-506

Kapatos ET, Fletcher BS (1986) Mortality factors and life-budgets for immature stages of the olive fly, Dacus oleae (Gmel.) (Diptera, Tephritidae), in Corfu. J Appl Entomol 102:326-342

Karuppaiah V, Sujayanad GK (2012) Impact of climate change on population dynamics of insect pests. World Journal of Agricultural Sciences 8(3):240-246

Lewis T (1997) Thrips as crop pests. CAB International, Oxon, GB. Lindroth RL, Kinney KK, Platz CL. 1993. Responses of deciduous trees to elevated atmospheric $\mathrm{CO} 2$ : productivity, phytochemistry and insect performance. Ecol. 74:763-777

Lopez-Villalta MC (1999) Olive pest and disease management. In: Proceedings International Olive Oil Council, Madrid, Spain, pp. 23.

Neuenschwander P, Michelakis S (1979) McPhail trap captures of Dacus oleae (Gmel.) (Diptera: Tephritidae) in comparison to the fly density by sondage technique in Crete, Greece. Bulletin Societe Entomologique Suisse 52:343-357

Ordano M, Engelhard I, Rempoulakis P, Nemny-Lavy E, Blum M, Yasin S, Lensky I, Papadopoulos N, Nestel D (2015) Olive Fruit Fly (Bactrocera oleae) Population Dynamics in the Eastern Mediterranean: Influence of Exogenous Uncertainty on a Monophagous Frugivorous Insect. PLoS One 10(5):1-18

Patterson DT, Westbrook JK, Joyce RJV, Lingren PD, Rogasik J (1999) Weeds, insects and diseases. Climate Change 43:711-727

Perović Tatjana, Hrnčić Snježana (2013) Population dynamics of pre-imaginal stages of olive fruit fly Bactrocera oleae Gmel. (Diptera, Tephritidae) in the region of bar (Montenegro). Pestic Phytomed. (Belgrade), 28(1) 23-29.

Pontikakos CM, Tsiligiridis TA, Yialouris CP, Kontodimas DC (2012) Pest management control of olive fruit fly (Bactrocera oleae) based on a locationaware agro-environmental system. Comput Electron Agric 87:39-50

Ricci C, Ballatori E (1982) Dinamica di popolazione degli adulti di Dacus oleae (Gmel.) Secondo incontro sul Dacus olea (Gmel.), Perugia. Frustula Entomologica, nuova serie 4:45-75

Root TL, Price JT, Hall KR, Schneider SH, Rosenzweig C, Pounds JA (2003) Fingerprints of global warming on wild animals and plants. Nature 421:57-60

Samways M (2005) Insect Diversity Conservation. Cambridge University Press, Cambridge, p 342

Varikou K, Garantonakis N, Birouraki A (2014) Response of olive fruit fly Bactrocera oleae to various attractant combinations, in orchards of Crete. Bulletin of Insectology 67(1):109-114

Vincent C, Hallman G, Panneton B, Fleurat-Lessardú F (2003) Management of agricultural insects with physical control methods. Annu Rev Entomol 48:261-281

Walther GR, Post E, Convey P, Menzel A, Parmesan C, Bee TJC (2002) Ecological responses to recent climate change. Nature 416:389-395

Wang XG, Johnson MW, Yokoyama VY, Pickett CH, Daane KM (2011) Comparative evaluation of two olive fruit fly parasitoids under varying abiotic conditions. BioControl 56(3):283-293

Yamamura K, Kiritani K (1998) A simple method to estimate the potential increase in the number of generations under global warming in temperate zones. Appl Entomol Zool 33:289-298
Yokoyama VY, Miller GT, Stewart-Leslie J, Rice RE, Phillips PA (2006) Olive fruit fly (Diptera: Tephritidae) populations in relation to region, trap type, season, and availability of fruit. J Econ Entomol 99:2072-2079

Yokoyama VY, Rendon PA, Sivinsk J (2008) Psyttalia cf. concolor (Hymenoptera: Braconidae) for biological control of olive fruit fly (Diptera: Tephritidae) in California Environ. Entomol. 37:764-773

\section{Publisher's Note}

Springer Nature remains neutral with regard to jurisdictional claims in published maps and institutional affiliations.

\section{Submit your manuscript to a SpringerOpen ${ }^{\circ}$ journal and benefit from:}

- Convenient online submission

- Rigorous peer review

- Open access: articles freely available online

- High visibility within the field

- Retaining the copyright to your article

Submit your next manuscript at $\boldsymbol{\nabla}$ springeropen.com 